\title{
SUGGESTED REMEDY FOR OBSTRUCTIONS TO EXPERT TESTIMONY BY RULES OF EVIDENCE
}

\author{
EDMUNd M. MORgaN*
}

$\mathrm{E}$ VERY discussion of the merits or demerits of our rules of evidence should begin with a reminder that a lawsuit is not a scientific investigation or primarily a proceeding for the discovery of truth. It is essentially a proceeding for the orderly settlement of a dispute between litigants. The composition of the tribunal whose functionit is to determine the factual basis for the settlement is prescribed by constitution or statute, drafted and enacted chiefly to attain desired political and social, rather than scientific, objectives. The conditions under which the tribunal is required to conduct its inquiries, the limits of time and of the means of investigation, are such as no scientist would tolerate. The questions to be answered are framed in unscientific terms and call for answers of legal rather than scientific significance. ${ }^{x}$ The scope of the inquiry is determined by the parties in two ways. First, they fix the issues in their pleadings or by other procedural devices; second, they furnish the evidence, for the courts have no machinery for independent, impartial investigation. ${ }^{2}$ To limit scientific search for facts in any such manner would be unthinkable.

* Royall Professor of Law, Harvard Law School.

I Much of the condemnation of the courts by members of the medical profession is due to failure to recognize this truth. Judicial opinions contain many words and phrases used with meanings other than those sanctioned by either common or scientific usage, and seem to state conclusions obviously opposed to currently accepted scientific verities. For example, lawyers say that insanity of an accused at the time of an offense is a defense, insanity at the time of the trial renders him immune from trial, and insanity at the time of sentence makes him immune from sentence. They know that the word, insanity, has in these three situations three different legal meanings, none of which coincides with the definition framed by alienists. Every competent alienist would say that a man may well be insane and still have the capacity to distinguish right from wrong and to realize the wrongfulness of specified conduct. Most courts would insist that so long as he retains this capacity, he is legally sane; but what they mean is simply that he is subject to certain prescribed treatment or disposition if he exhibits certain specified anti-social conduct. Similarly, experts in mental and emotional diseases have no patience with judges who talk of an accused's responsibility for his conduct. To the judges responsibility means only liability to prescribed treatment or disposition on account of specified objective conduct; to the experts it may be meaningless in such connection.

2 The court has the right and power to call witnesses of its own motion; but does so only in unusual circumstances. Generally, no evidence is offered except that produced by the parties. 
Most of these restrictions upon free and full investigation are concomitants of our adversary system. The adjustment of legal relations between the parties is the object of the lawsuit. The decision as to the facts affects only the parties and those claiming through them. It is therefore reasonable to have the parties define the area of dispute, so as to avoid unnecessary expenditure of time, money, and effort. It is likewise reasonable to suppose that the persons most interested in the result will be most diligent in discovering and presenting pertinent evidence. Each party may be expected to reveal and emphasize the strength of his own case and the weakness of that of his adversary, so that the facts will be made apparent to an impartial tribunal. If equality of industry and skill in preparation and presentation by the adversaries and their representatives be assumed, the system is almost ideal. But experience demonstrates that such equality rarely exists and the disastrous effects of the inequalities are magnified by the operation of technical rules of procedure, particularly rules governing the presentation and admissibility of evidence. Nowhere are these inequalities more glaring than in the field of expert testimony, partly because the expert has become an advocate rather than a witness, and partly because of rules which permit the suppression of important data, which sanction the exclusion of relevant evidence, and which restrict the use of opinion. ${ }^{3}$ All rules which prevent consideration of any relevant material hamper the intelligent expert, but the rules as to privilege, hearsay, and opinion are especially pernicious.

\section{Privileges}

The common law privilege against the disclosure of communications between husband and wife and the privilege against revelation of communications of penitent to priest rarely operate to limit the work of the expert. The same is largely true of the privilege of a client that communications between him and his lawyer be not disclosed. The privilege against selfincrimination, however, has in some states been perverted to prohibit the use of highly reliable scientific evidence. For example, the victim of a rape is found to be suffering from a venereal infection. The accused is arrested and examined to ascertain whether he is afflicted with the same disease, and if so, what is the stage of its development, and other related

3 Fortunately, most of the common law disqualifications of persons to be witnesses have been abolished. In most states, however, there is a statutory disqualification of interested persons to testify against the estate of a decedent or incompetent. The disqualifying provisions are various, some more hampering than others. Only infrequently do they affect expert evidence, and then only by preventing the use of data as to which the interested persons alone have testimonial knowledge. The harm done by this unwise attempt to protect the property of decedents or incompetents from false claims is chiefly in other fields. 
matters. Or the driver of an automobile or other vehicle is arrested after an accident, and a sample of his saliva or urine or blood is taken over his protest. The sample is analyzed to determine what percentage of alcohol, if any, it contains. The data obtained from the physical examination of the accused or from the analysis of his body fluids are sought to be used as a basis for the opinion of expert witnesses in either a criminal prosecution or a civil action for damages. Some courts have held that the experts may not testify because the examination of the body or the taking of the samples constituted an infringement of the defendant's privilege against selfincrimination. ${ }^{4} \mathrm{Mr}$. Wigmore has shown that the privilege was created to protect men from: "the employment of legal process to extract from the person's own lips an admission of his guilt, which will thus take the place of other evidence. Such was the process of the ecclesiastical Court, as opposed through two centuries - the inquisitorial method of putting the accused upon his oath, in order to supply the lack of the required two witnesses.....

"In other words, it is not merely any and every compulsion that is the kernel of the privilege, in history and in the constitutional definitions, but testimonial compulsion."s

Many modern enlightened courts take the same view, and, in its Model Code of Evidence published in I942, the American Law Institute has approved it in Rule 205, which provides that the privilege against self-incrimination does not include any privilege of a person to refuse " $(a)$ to submit his body to examination for the purpose of discovering or recording his corporal features and other identifying characteristics, or his physical or mental condition, or $(b)$ to furnish or to permit the taking of samples of body fluids or substances for analysis."

The common law recognized no privilege covering communications between patient and physician. Many legislatures have created such a privilege, and it has been used as a most serious clog on honest expert evi-

4 People v. Corder, 244 Mich. 274, 22I N.W. 309 (r928), adversely commented on in 29 Col. L. Rev. 214 (1929.) (physical examination for venereal disease). State v. Weltha, $228 \mathrm{Ia} .519$, 292 N.W. 148 (1940) (held that a compulsory taking of body fluids constitutes an illegal search). The intimation is that the admission of such evidence also violates the privilege against self-incrimination. The case is subjected to adverse criticism in 26 Iowa L. Rev. 137 (I940). The few cases involving the use of samples of blood and other body fluids are discussed in I7 Notre Dame Lawyer 243 (1942). For a full discussion of the problem, see Ladd and Gibson, The Medico-Legal Aspects of the Blood Test to Determine Intoxication, 24 Iowa L. Rev. I9I, 218-4I (1939).

58 Wigmore, Evidence $\$ 226_{3}$ ( $3 \mathrm{~d}$ ed. I940). See a similar statement by Mr. Justice Holmes in Holt v. United States, 218 U.S. 245, 252-53 (I9I0), "But the prohibition of compelling a man in a criminal court to be witness against himself is a prohibition of the use of physical or moral compulsion to extort communications from him, not an exclusion of his body as evidence when it may be material." 
dence. Because many judges have said that it is difficult to refuse a physician-patient privilege while enforcing a lawyer-client privilege, and because most arguments are built on the hypothesis that the latter is founded on reason and justified by compelling considerations of social policy, that privilege must be first examined.

The origin of the lawyer-client privilege is easily explained. There was no compulsory process for witnesses in England until the time of Elizabeth. At that time also there was much inclination to give legal recognition to men's instinctive repulsion against violating a confidence. It was, therefore, to be expected that the attorney, an officer of the court as well as the representative of the client, should not be compelled to take the role of a witness and violate the code of honor of a gentleman. But the privilege was strictly the privilege of the attorney. The client was bound by no obligation of honor not to reveal the communication, and he could be compelled to do so by a bill of discovery.

Such solicitude for the honor of the attorney, however, could not long be justified, when other men were compelled, because of the higher duty to aid the state in the administration of justice, to suppress their scruples and disclose matters revealed in confidence. Other reasons were then found in the supposed benefits to the administration of justice by inducing the client to lay bare everything to the lawyer. These, however, were no support for a lawyer's privilege: if the client had to testify to the communication, he would be little comforted by the assurance that his lawyer could not be compelled to do so. Consequently, what had been the privilege of the lawyer became the privilege of the client. Today, no one questions the client's right to prevent the lawyer's disclosure or the lawyer's obligation to disclose if the client consents.

The argument for the privilege runs like this. (I) The relation of lawyer and client is one to be fostered by society. (2) If the lawyer is to perform his full function to the client and society, he must know all the facts. (3) The client will not reveal facts which he believes to be to his disadvantage unless he knows that the lawyer cannot be compelled to disclose. (4) The harm done by the supression of relevant material in individual cases is more than offset by the general benefit to the community by thus fostering the relation. .

No informed person would deny that in our complex, highly industrialized society, men learned in the art of discovering and interpreting applicable legal rules are necessary if citizens are to know their legal rights and duties. Furthermore, with existing rules of procedure and evidence, laymen can conduct litigation only with great risk of loss to themselves 
and unnecessarily great expense to the community. Hence, it may be granted that the relationship of lawyer and client deserves strong social approval. It may well be conceded, also, that if the lawyer is to give sound advice, to bring no unfounded action, and to interpose no baseless defense, he must know all the facts. It is likewise reasonable to assume that when a client consults a lawyer, he contemplates actual or potential litigation, or an administrative or legislative investigation, where all pertinent material will be sought.

Will he suppress relevant material detrimental to his interest unless he knows that his revelations will be kept secret? If so, who will be harmed? If he gets the same advice that he would have received on full disclosure, no one is hurt. If he gets bad advice and acts on it to his detriment, whom has he to blame but himself, and why should society seek to protect him from his own deliberate folly or dishonesty? If a lawsuit results, he is subject to compulsory process as a witness, whether he is a party to the action or not. On the witness stand he must undertake to tell the truth, under penalty for perjury. If he told the truth to his lawyer, he must tell the same story in court, and any testimony from the lawyer is unnecessary and would be harmless. If he told a lie to his lawyer and repeats the lie in court, the same is true. If he told his lawyer a lie and now tells the truth, or if he told his lawyer the truth and now tells a lie, why should he be saved from the consequences of his own deliberate falsehood? Surely a privilege to suppress the truth is not to be created for the encouragement and protection of perjurers.

And how can the community be benefited? How many baseless claims would be made the subject of suit and how many valid claims would be unjustifiably resisted because of the client's failure to disclose, were the privilege abolished? Any answer would be pure conjecture. The privilege certainly has not eliminated such claims and defenses. Many a lawyer has been deceived by his client, and the deception has been costly to both. Only the crooked client will deliberately suppress relevant matter. If such a client knows what will constitute a good claim or defense, he will adjust his evidence to fit the requisites. The books bear witness to a common experience in the profession. Mr. Client consults Attorney Adams and is informed that he has no cause or defense because the facts lack element $X$. Later Mr. Client, represented by Attorney Baston, sues or defends with pleadings averring and evidence asserting the existence of $\mathrm{X}$. How many of these cases would be avoided by the abolition of the privilege? It is just as easy to maintain that the privilege results in positive harm to society as that it causes benefits to society outweighing the damage it con- 
cededly does to litigants in contested cases. ${ }^{6}$ Therefore, the existence of the lawyer-client privilege can be the basis of no sound argument for the creation of a privilege covering communications between physician and patient.

If such a privilege will materially promote the public health, its obstruction to the proper conduct of litigation may be justified. It goes without saying that the physician-patient relationship is one to be fostered. Protection of the health of the individual is essential to societal well-being. It is axiomatic, too, that the patient must reveal his subjective condition and submit his body to inspection and examination if he is to receive suitable treatment and advice. Of course, most persons would hesitate to disclose their secret symptoms and expose their bodies to a physician free to advertise the infirmities thus discovered. To say that the patient has no privilege to prevent disclosure is not to say that the physician has a privilege of indiscriminate disclosure, or to say that he is not under a duty to the patient to refuse to disclose except in discharge of a higher duty to the public. The question is whether the patient will be deterred from making proper revelations unless he knows that he can prevent the physician from testifying to what he learned from the patient in a future lawsuit in which the patient's condition is a material matter. To answer in the affirmative is to assume that the patient anticipates such a lawsuit, that the condition is one which he wants kept secret, and either that he does not know what he can be compelled to disclose as a witness or that in case he is called as a witness he expects to commit perjury or contempt of court.

Ordinarily a patient does not object to a dignified disclosure of his physical condition on a proper occasion, unless he is suffering from a disease ordinarily considered loathsome or disgraceful. Physicians are usually required to report such a disease to public authority and thus to make its existence a matter of public record. Certainly the typical citizen would much rather take a chance on having such matter brought out by the physician in a lawsuit than to endure the certainty that it would be recorded in a public office open to the eyes of subordinate clerks and employees, if not to the public. And this would be doubly true if he knew the truth that in such a lawsuit he could himself be made a witness and required to answer all pertinent questions as to his symptoms, objective and subjective, past and present. Consequently, the assumption that patients

\footnotetext{
${ }^{6}$ The constitutional privilege against self-incrimination and the right to counsel in criminal cases may require that self-incriminating communications to counsel be protected against compulsory disclosure.
} 
are deterred from full disclosure by reason of their desires for secrecy in future litigation has little or no basis in reason.

Nor is there any objective evidence that the existence of the privilege has had any influence in promoting public health or that its absence has had an adverse influence. New York has had the privilege longer than any other state. Are residents of New York any the more ready to consult physicians than residents of Massachusetts where the privilege has never been recognized? Do the people of Mississippi since I 906 show any less reluctance to seek medical treatment than before that year, in which the personal injuries lawyers succeeded in securing legislative enactment of the privilege? Have the physically afflicted shunned the famous physicians and surgeons of Baltimore because Maryland denies any such privilege? No one has had the temerity to assert that progress in medical science in England, in Maryland, in Massachusetts has been deterred in the slightest degree by their adherence to the common law rule, or that the development of the science and art of healing has been advanced in any measure in any state by the presence of the privilege. In short, there is nothing to demonstrate any benefit to the public in the privilege, while the law books are full of instances where its application has prevented the discovery of the truth to the damage of honest litigants.

In these circumstances, if any privilege is to be created, it should be so limited as to prevent the abuses which experience has revealed in cases where the patient is making his physical or mental condition a basis for his claim or defense. It should also be of no avail where it would aid a criminal to escape detection. The proposal of the American Law Institute contains most of the desirable limitations. It confines the privilege to civil actions and prosecutions for misdemeanors, and makes it inapplicable ( $I$ ) to information which the physician or the patient is required to report to a public official or to information required to be recorded in a public office, unless the statute requiring the report or record specifically provides that the information shall not be disclosed, or (2) in an action in which the condition of the patient is an element or factor of the claim or defense of the patient or of any party claiming through or under the patient or claiming as a beneficiary of the patient through a contract to which the patient is or was a party, or (3) upon an issue of the patient's condition in an action to commit him or otherwise place him under the control of another or others because of alleged mental incompetence, or in an action in which the patient seeks to establish his competence or in an action to recover damages on account of conduct of the patient which constitutes a criminal offense other than a misdemeanor, or (4) upon an issue 
as to the validity of a document as a will of the patient, or (5) upon an issue between parties claiming by testate or intestate succession from a - deceased patient. ${ }^{7}$

\section{HEARSAY AND OPINTON}

There are two situations in which the hearsay rule interferes peculiarly with the effective use of expert evidence. First, it makes inadmissible pertinent materials in learned treatises, and in most jurisdictions prevents their use even on cross-examination of witnesses. Second, in many states it prohibits an expert from giving an opinion based in part on hearsay. The latter is particularly annoying to the medical expert, since it often compels him to disregard data which no physician or surgeon would dream of neglecting. Both these absurdities are abrogated in the Model Code of Evidence of the American Law Institute. ${ }^{8}$

The rules governing so-called opinion evidence as developed and applied in this country are extremely unsatisfactory. They put irrational restrictions upon both lay and expert witnesses. They do not greatly hamper the expert who is testifying simply to what he has observed, except when his testimony is phrased in terms of inference, and this inference is an answer to a so-called ultimate question to which the jury must give a final answer. There is much senseless talk about the usurpation by the witness of the function of the jury and much obscure discussion of the distinction between an ultimate and a non-ultimate issue.

This same dogma is applied with greater vigor where the expert is giving an opinion based wholly or in part upon a hypothesis of facts to which others have testified. It is in such situations and in those where the importance of the testimony lies not in the data observed but in the expert's deduction from the data, that the expert's opinion will be most helpful to the trier of fact. Unfortunately, it is in just these cases that the existing rules have become intolerable in modern practice.

This regrettable result is due in no small measure to the fact that the usual expert witness assumes the role not of an impartial specialist but of an ardent advocate of the party who has retained him. In litigation in-

7 These limitations on privilege are embodied in the American Law Institute, Model Code of Evidence, Rules 220-23, 23I-32 (I942).

${ }^{8}$ Rule 529 provides: "A published treatise, periodical or pamphlet on a subject of history, science or art is admissible as tending to prove the truth of a matter stated therein if the judge takes judicial notice, or a witness expert in the subject testifies, that the writer of the statement in the treatise, periodical or pamphlet is recognized in his profession or calling as an expert in the subject." Rule 503 makes admissible hearsay statements of matters within the knowledge of the declarant, if the declarant is unavailable as a witness, or if he is present and subject to cross-examination. Thus, it will always be possible to present the data upon which the expert witness bases his opinion. 
volving personal injuries, death by accident, alleged mental irresponsibility and the like, the medical expert has become a stench in the nostrils of upright judges. He disgraces his own profession and the legal profession which uses and tolerates him. Combinations between crooked doctors and shyster lawyers impose upon honest jurors and defraud public service companies and insurance corporations. Even the generally respected physician and surgeon whose skill is unquestioned frequently shades his testimony to the advantage of the party paying his fee. Alienists are notoriously available for prosecution and defense in sensational criminal trials. In other fields, the evil is just as virulent but not so noticeable because the opportunities for its exhibition are fewer. In litigation involving disputed documents, the scientific, impartial expert is conspicuous because of his scarcity. Even chemists appearing as expert witnesses have testified as to the same samples in such manner as to make it difficult to assume any serious attempt at honest analysis.

So long as corrupt men are permitted to practice law and venal men are able to qualify as expert witnesses, this evil cannot be entirely eradicated. It can, however, be greatly mitigated and its consequences reduced to a minimum by having the court appoint impartial experts who appear as witnesses for neither party but for the court, having the trier of fact informed that these experts have been thus appointed, and requiring partisan experts to act on adequate data and to submit their conclusions in writing to the scrutiny of the court and the parties. It might be well if the parties could be prevented from calling any expert not approved by the court, but that is too much to propose, at least for the present. The American Law Institute Code, embodying for the most part the recommendations of the Uniform Law Commissioners, provides that whenever the judge determines that expert evidence will be of substantial assistance in an action, he may of his own motion or at the request of a party appoint one or more expert witnesses to give evidence in the action. The parties have a right to be heard as to the necessity or advisability of appointing any experts and as to the choice of experts. They may call other experts if they give notice in advance. Experts appointed by the court may be cross-examined by both parties, and the jury is to be informed that they were so appointed. These provisions properly applied would assure the trier of fact of the aid of competent impartial experts expressing unbiased opinions.

But the Code does not stop here. It attempts to insure opinions based on adequate grounds. Rule 405 authorizes the judge to require each party to submit to the experts for examination and inspection all persons, things, 
and places under his control, and to require each expert witness, whether appointed by the court or selected by a party, to make all necessary inspection and examination. The judge also is given power to require each expert to file a written report under oath which shall be open to inspection by the parties, and to require two or more experts to confer and where practicable to join in a report. Thus are minimized the opportunities for unscrupulous experts to deceive the trier of fact by plausible theories based on incomplete information.

Another cause for dissatisfaction with the currently applied rules is found in the misuse and abuse of the hypothetical question. That the expert's opinion must be only hypothetically usable by the trier of fact is inherent in our system of trial. Either the jury or the judge or some other person or body acting officially as trier must find the facts. Ordinarily, the credibility of a witness, expert or non-expert, is to be determined by the trier. Only when the witness is disinterested, unimpeached, and uncontradicted, and tells a story not inherently improbable is the trier obliged to credit his testimony. Consequently, even where the expert is testifying to what he has personally observed and states his deductions therefrom, the jury is not ordinarily bound to believe that his account of his observations is accurate; and his deductions are beside the point if the foundation for them is non-existent. Where the expert is called merely to give his opinion or conclusions on a state of facts which he has not personally seen or heard, his testimony will be of no help to a trier of fact which decides that the specified state of facts does not exist in the action. And where there is a dispute in the testimony as to the facts, neither the expert nor any other witness can be permitted to decide that dispute. ${ }^{9}$ An ex-

9 While this rule is theoretically sound and sensible, its application is frequently overtechnical and unintelligent. For example, see State v. David, 22 S.E. (2d) 633, decided by the Supreme Court of North Carolina in November, 1942. That was a prosecution for murder in which it was material for $P$ to prove the cause of death. A month after the death, the body was disinterred and sent to a hospital for an autopsy. Dr. W performed this autopsy, turning over to $\mathrm{Dr}$. X some portions of the body for subsidiary examination and report. W was asked as to his opinion about the cause of death on the basis of $(a)$ his personal observations, $(b)$ what he had been told about the history of the case, and $(c)$ an assumption of certain jury findings with respect to specified material facts. In the course of his response to the line of interrogation which grew out of this question, $W$ testified that the factor above lettered $(b)$ influenced his findings "only in an immaterial way." He stated as his opinion that death had been caused by carbon monoxide, and also stated that he found no other cause for death. $X$ testified that he had been present most of the time the autopsy was being performed, that he examined the parts of the body turmed over to him, and the only significant poisonous material present was carbon monoxide, and that by reason of the discovery of this substance and the absence of other causes of death, as indicated in the conclusions of $W$ and also on the basis of certain specified assumptions as to jury findings, $X$ had reached the conclusion that death was due to carbon monoxide. Being convicted, D appealed. Held, there was error. X's testimony was improperly based upon X's views as to the credibility of W's testimony, rather than upon an assumption of 
pert, after hearing the conflicting testimony, may be convinced that the facts are thus and so, and that the witnesses who testify otherwise are lying or mistaken, but the trier of fact is under no obligation to agree with him.

All this makes the hypothetical question a sound and sensible device. The honest opinion of the competent expert will be of great assistance to the jury. If the facts are $A+B$, then his opinion is $X$; if $C+D$, then $Y$. The jury may find either state of facts, and will apply the opinion to the facts found. Consequently, counsel may seek the expert's opinion on each state of facts which may reasonably be found on the evidence, but not on any other. This leads to many confusing arguments concerning the propriety of proposed questions. Furthermore, if the court adheres to the dogma which forbids the expert's opinion upon an ultimate issue for the jury, ${ }^{\text {xo }}$ the question may have to be framed in a totally unintelligible way,

a jury finding with respect to what W asserted. Furthermore, W's testimony was not testimony of fact but testimony of opinion, and it is improper to admit evidence of the opinion of one expert based upon the subsidiary opinion of another expert. The questions and answers involved in the examination of $X$ and $W$ are set out with reasonable fullness, and make it clear that by a slight change in form, the objections would have been avoided, and exactly the same impression created in the mind of the average hearer.

ro It is interesting to contrast the opinion of the Supreme Court of North Carolina in Patrick v. Treadwell, 2I S.E. (2d) 8r 8, decided September 23, I942, with that of the Supreme Court of Iowa in Grismore v. Consolidated Products Co., 5 N.W. (2d) 646, decided September 29, I942. In the former, the plaintiff was seeking recovery for injury alleged to have been caused by a collision between two automobiles. The plaintiff, who was riding in one of the automobiles, had previously suffered a fracture of her arm which had been properly set and was then in a cast. A question to the expert assumed in effect that the arm had been properly set, and that by the force of the collision the plaintiff was thrown from the seat to the floor of the car so that the cast was broken, and asked whether he had an opinion what caused the fresh injury to her arm.

"A. I have an opinion. It seems any violent blow or fall or jar or anything hard enough to break a cast would naturally break the fragments that had not had time to grow together properly.

"Q. Further assuming that the jury should find as a fact from the evidence and by its greater weight that that was the only act of external violence which she had sustained between the dates of July IIth and July Igth, have you such an opinion?

"A. Yes, I believe the accident caused the breaking of the cast and also caused the fragments of the bone to be knocked out of place.

"Q. You mean by that the automobile accident which we are talking about?

"A. Yes, sir.

“Q. You don't know what caused the dislocation of the bone?

"A. I know the accident did it, or whatever occurred."

The court, after pointing out that the expert might in proper cases express a scientific opinion even though it were on the very issue before the jury, said: "Undoubtedly it would be competent for an expert witness to give his opinion as to what causes would produce the result observed, but this would not permit him to inject into the consideration of the jurors the weight of his assertion that such result was in fact produced by a particular cause." For error in permitting the foregoing answers a new trial was ordered.

In the Iowa case, the court reviewed numerous earlier Iowa decisions as well as many from other jurisdictions. It overruled some previous decisions and held flatly that "there can no longer be any question of the soundness of the rule that if the matter before the tribunal for 
as for example, not as to any actual human being who is assumed to have exhibited specified conduct, but as to a hypothetical person who has exhibited assumed conduct. The result is, as Mr. Wigmore so well puts it::

The hypothetical question, misused by the clumsy and abused by the clever, has in practice led to intolerable obstruction of truth. In the first place, it has artificially clamped the mouth of the expert witness, so that his answer to a complex question may not express his actual opinion on the actual case. This is because the question may be so built up and contrived by counsel as to represent only a partisan conclusion. In the second place, it has tended to mislead the jury as to the purport of actual expert opinion. This is due to the same reason. In the third place, it has tended to confuse the jury, so that its employment becomes a mere waste of time and a futile obstruction.

Rules 408 and 409 of the Code will do much to enable experts to give their testimony in a manner satisfactory to themselves and understandable by the jury or other trier of fact.

These two rules provide (a) that "An expert witness may at the trial read in evidence any report which he made or joined in making except matter therein which would be inadmissible if offered as oral testimony by the witness," and (b) that "An expert witness may state his relevant inferences from matters perceived by him or from evidence introduced at the trial and seen or heard by him or from his special knowledge, skill, experience or training, whether or not any such inference embraces an ultimate issue to be decided by the trier of fact, and he may state his reasons for such inferences and need not, unless the judge so orders, first specify, as a hypothesis or otherwise, the data from which he draws them; but he may thereafter during his examination or cross-examination be required to specify those data."

determination is one in which opinion testimony, either lay or expert, is necessary or proper, the witness may express his opinion either as to the possibility, probability, or actuality of the matter of fact about which he is interrogated, and the answer will not be an invasion or usurpation of the province or function of the jury, even though it passes upon an ultimate fact which the jury must determine."

II 2 Wigmore, Evidence $\$ 686$ (3d ed. 1940).

12 The other Rules governing expert and opinion evidence are as follows:

RULE 4 OT. TESTIMONY IN TERMS OP OPINION

(I) In testifying to what he has perceived a witness, whether or not an expert, may give his testimony in terms which include inferences and may state all relevant inferences, whether or not embracing ultimate issues to be decided by the trier of fact, unless the judge finds

(a) that to draw such inferences requires a special knowledge, skill, experience, or training which the witness does not possess, or

(b) that the witness can readily and with equal accuracy and adequacy communicate what he has perceived to the trier of fact without testifying in terms of inference or stating inferences, and his use of inferences in testifying will be likely to mislead the trier of fact to the prejudice of the objecting party.

(2) The judge may require that a witness, before testifying in terms of inference, be first examized concerning the data upon which the inference is founded.

RUIE 402, EXPERT WITNESS DEFINED

A witress is an expert witness and is qualified to give expert testimony if the judge finds that to perceive, know or understand the matter concerning which the witness is to testify requires special knowledge, skill, experience or training, and that the witness has the requisite special knowledge, skill, experience or training. 


\section{CONCLUSTON}

Speaking generally, the American Law Institute, in its Model Code of Evidence, restores to the trial judge his common law powers to govern the trial and gives him great discretion over the conduct of counsel and witnesses. It forbids reversals for errors which do not materially prejudice substantial rights. It makes most hearsay evidence admissible and provides a sensible, understandable use of expert and opinion evidence. If adopted, it will make the unscrupulous expert less effective in his attempts to deceive. It will make the task of the honest expert witness less distasteful and enable him to render invaluable aid to juries and other triers of fact.

RULE 403. APPONNTIENT OP EXPERTS

In an action in which the judge determines that expert evidence will be of substantial assistance, he may, of his own motion or at the request of a party, at any time during the pendency of the action

(a) order the parties

(i) to show cause why expert witnesses should not be appointed to give evidence in the action, and

(ii) to submit nominations for their appointment, and objections to proposed appointments, and

(b) appoint one or more expert witnesses of his own selection to give evidence in the action except that, if the parties agree as to the experts to be appointed, he shall appoint only those designated in the agreement.

ROLE 404. TESTMYNY BY OTHER EXPERTS

Subject to Rule ro5(c), a party may call an expert witness who has not been appointed under Rule 403, if the judge finds that

(a) the party has given reasonable notice to each adverse party of the name and address of the witness to be called, or (b) it is expedient, notwithstanding a failure to give such notice, to permit the witness to be called.

RULE 405. EXA3MNATION AND REPORT BY EXPERTS

(r) At any time after the appointment of an expert witness by the judge, or after notice of intention of a party to call an expert witness, the judge, on his own motion or that of a party, after reasonable notice to each party and hearing thereon, may make one or more of the following orders:

(a) that each party submit, for purposes of inspection and examination by each expert witness named in the order, his person and all persons, things and places under his control insofar as the judge deems necessary to enable the witness adequately to inform himself for the purpose of testifying;

(b) that at the time and place and under reasonable conditions set forth in the order each expert named therein make such inspection and examination of the person, thing, place or matter concerning which he is to give evidence as the judge deems necessary;

(c) that any expert witness prepare and file with the clerk of the court within a time fixed in the order a written report under oath of the inspection and examination made by him, including the inferences drawn by him therefrom;

(d) that two or more of the expert witnesses confer at or before a time fixed in the order and, if practicable, unite in a written report and file it with the clerk of the court.

(2) No inspection or examination ordered by the judge under this Rule shall be made unless each party has been given reasonable notice thereof and opportunity to be appropriately represented.

(3) On motion of a party or of a person having an interest in the subject matter of an inspection or examination ordered by the judge under this Rule, the judge shall determine the scope and manner of the inspection or examination or of any part thereof, as to which a dispute has arisen either before or during the inspection or examination.

RULE 406. REPORTS OPEN TO INSPECTION

Each report filed pursuant to Rule 405 shall be open to inspection by each party to the action immediately after filing. No expert witness who made or joined in making a report shall be called as a witness until a reasonable time after the filing of the report.

RULE 407. EXAMTNATION OF EXPERT APPONNTED BY JUDGE

An expert witness appointed by the judge may be called as a witness by the judge or by a party and may be examined by each party as if the ritness had been called by an adverse party. The fact of the appointment by the judge shall be made known to the trier of fact.

RULE 4IO, CONPENSATION OF EXPERT WITNESS

The compensation of each expert witness appointed by the judge shall be fixed at a reasonable amount. In a criminal action it shall be paid by [insert name of the proper public authority] under order of the judge. In a civil action it shall be paid as the judge shall order; he may order that it be paid by the parties in such proportions and at such times as he shall prescribe, or that the proportion of any party be paid by linsert name of the proper public authorily], and that, after payment by the parties or [insert name of the proper public authority] or both, all or part or none of it be taxed as costs in the action. Any witness appointed by the judge who receives any compensation other than that fixed by the judge and any person who pays or offers or promises to pay such ofher compensation shall be guilty of contempt of court. The fee of an expert witness called by a party but not appointed by the judge shall be paid by the party calling him but shall not be tared as costs in the action. 